\title{
KRITERIA DIAGNOSIS DAN PENATALAKSANAAN OTITIS MEDIA SUPURATIF KRONIS
}

\author{
Fairuziah Binti Bader Alkatiri \\ Program Studi Pendidikan Dokter, Fakultas Kedokteran Universitas Udayana \\ ziaalkatiri@gmail.com
}

\begin{abstract}
ABSTRAK
Pendahuluan: Otitis media merupakan peradangan sebagian atau seluruh mukosa telinga tengah, tuba Eustachius, antrum mastoid, dan sel-sel mastoid. Pasien dengan penyakit telinga tengah seringkali datang saat stadium kronis yang menyebabkan kehilangan pendengaran dan pengeluaran sekret. Pasien mengeluhkan gangguan pendengaran yang mengganggu fungsi sosial, pendidikan dan profesi. Anak usia sekolah mungkin memperlihatkan hasil yang buruk di sekolah. Salah satu jenis otitis media adalah Otitis Media Supuratif Kronik (OMSK), yang merupakan infeksi kronik telinga tengah dengan perforasi membran timpani dan keluarnya sekret dari telinga tengah secara terus menerus atau hilang timbul, biasanya disertai gangguan pendengaran. Sekret mungkin encer atau kental, bening atau berupa nanah. OMSK dulu disebut otitis media perforata. Diagnosis OMSK ditegakkan berdasarkan anamnesis, pemeriksaan fisik. Dua jenis klasifikasi yang sering digunakan yaitu OMSK tipe benigna dan tipe maligna, dan berdasarkan aktivitas sekret yang keluar (OMSK aktif dan OMSK tenang). Penatalaksanaan tuli mendadak meliputi terapi konservatif dengan beberapa medikamentosa tergantung dari tipe OMSK dan komplikasi yang menyertai.
\end{abstract}

Kasus: Pasien laki-laki, 47 tahun, datang dengan keluhan keluar cairan dari telinga kiri sejak 1 bulan yang lalu. Cairan yang keluar berwarna putih kekuningan, sedikit kental, tidak berbau, keluar sedikitsedikit, dan tidak disertai rasa gatal. Pasien mempunyai riwayat diabetes. Pasien mengaku sebelumnya air sempat masuk ke telinga saat berenang di laut. Pada status present dan status generalis dalam batas normal. Pada telinga kiri ditemukan sekret mukopurulen. Pada membran timpani kiri tampak perforasi pada bagian sentral regio postero superior.

Kata Kunci:otitis, kronis, telinga

\section{ABSTRACT}

Introduction: Otitis media is an inflammation of part or all of the mucosa of the middle ear, Eustachian tube, mastoid antrum, and mastoid cells. Patients with middle ear disease often comes as a chronic stage that causes hearing loss and expense secretions. Patients complain of hearing loss that disrupt the function of the social, educational and professional. School-age children may show poor results at school. One type of otitis media is chronic suppurative otitis media (CSOM), which is a chronic infection of the middle ear with tympanic membrane perforation and discharge of secretions from the middle ear continuous or intermittent, usually accompanied by hearing loss. Secretions may be thin or thick, clear or in the form of pus. CSOM formerly called otitis media with perforated. Diagnosis is made by history, physical examination. Two types of classification that is often used is CSOM types of benign and malignant types, and based on the activity of secretions out. Management of sudden deafness include conservative with some medical therapy depends on the type of CSOM and accompanying complications.

Case: Male patient, 47 years old, came with complaints of discharge from the left ear since 1 month ago. Discharge yellowish-white, slightly viscous, odorless, out a little, and not itchy. Patients with a history of diabetes. Patients admitted before the water could get into the ear while swimming in the sea. At the present status and status generalist within normal limits. On the left ear found 
mucopurulent secretions. On the left tympanic membrane perforation in the visible region of the central part postero superior.

Keywords:otitis, chronic, ear.

\section{PENDAHULUAN}

Otitis media adalah inflamasi pada sebagian atau seluruh mukosa telinga tengah, tuba Eustachius, antrum mastoid, dan sel-sel mastoid. Jika prosesnya terjadi lebih dari 12 minggu maka disebut kronik. Dikatakan suatu proses kronik (OMSK) ialah infeksi kronik di telinga tengah dengan perforasi membran timpani dan sekret yang keluar dari telinga tengah terus menerus atau hilang timbul. Batasan waktu menurut kebanyakan ahli THT adalah 2 bulan, namun batasan menurut WHO adalah 12 minggu untuk penegakan diagnosis OMSK. ${ }^{2,3,5}$

Otorea dan supurasi kronik telinga tengah dapat menunjukkan pada pemeriksaan pertama sifat-sifat dari proses patologi yang mendasarinya. Umumnya otorea pada otitis media kronik bersifat purulen (kental, putih), atau mukoid (seperti air dan encer) tergantung stadium peradangannya. Sekret mungkin juga encer atau kental, bening atau berupa nanah. ${ }^{2}$

Jenis bakteri yang paling banyak diisolasi pada OMSK adalah P. Aeruginosa, S. Aureus, Corynebacterium, dan Klebsiella pneumoniae. Organisme anaerobik seperti Peptostreptococcus, Fusobacterium species, Propionibacterium acnes, dan Bacterioides species, juga umum diisolasi. Lain halnya dengan yang ditemukan pada OMA, dimana organisme anaerob hanya memainkan peranan kecil dalam patogenesisnya.

WHO mengklasifikasikan prevalensi OMSK sebagai negara prevalensi paling tinggi $(>4 \%)$, tinggi (2$4 \%)$, rendah (1-2\%), dan paling rendah $(<1 \%)$. Prevalensi OMSK di Indonesia 3,9\% sehingga termasuk negara prevalensi tinggi. Negara berprevalensi paling tinggi yaitu Tanzania, India, Kepulauan Solomon, Guam, Aborigin, Australia, dan Greenland. ${ }^{3}$ Dua jenis klasifikasi yang sering digunakan yaitu OMSK tipe benigna dan tipe maligna, dan berdasarkan aktivitas sekret yang keluar (OMSK aktif dan OMSK tenang). ${ }^{2,3}$

Tipe benigna adalah tipe tubotimpanik karena biasanya didahului dengan gangguan fungsi tuba yang menyebabkan kelainan di kavum timpani, disebut juga tipe mukosa karena proses peradangan biasanya hanya di mukosa telinga tengah. Disebut tipe aman karena jarang menimbulkan komplikasi berbahaya. Sedangkan tipe maligna adalah tipe atiko-antral karena biasanya proses dimulai di daerah tersebut, disebut juga tipe tulang karena penyakit ini menyebabkan erosi tulang. ${ }^{3}$

OMSK tipe aktif adalah OMSK dengan sekret yang keluar dari kavum timpani secara aktif, sedangkan tipe tenang adalah yang keadaan kavum timpaninya terlihat basah atau kering. ${ }^{2}$

Pada prinsipnya penegakan diagnosis OMSK berpedoman atas hasil dari pemeriksaan klinis (anamnesis dan pemeriksaan fisik) serta dapat dibantu dengan pemeriksaan penunjang lain. Dari anamnesis didapatkan riwayat otorea menetap atau berulang lebih dari 2 bulan. OMSK yang terbatas di telinga tengah hanya menyebabkan tuli konduktif. Bila terdapat tuli campur dapat menandakan komplikasi ke labirin. ${ }^{8}$

Pada OMSK benigna diusahakan epitelisasi tepi perforasi melalui tindakan poliklinik dengan melukai pinggir perforasi secara tajam atau dengan mengoleskan zat kaustik seperti nitras argenti $25 \%$, asam trichlor asetat $12 \%$, alkohol absolut, dll. Dalam pemilihan antibiotik harus diingat: pada OMSK telah terjadi perubahan yang menetap, resolusi spontan sangat sulit terjadi dan biasanya ada gangguan vaskularisasi di telinga tengah sehingga antibiotik sistemik sukar mencapai sasaran dengan optimal, kronisitas dengan fase aktif dan fase tenang yang bergantian dapat terjadi sepanjang umur maka diperlukan antibiotika pada setiap fase aktif, pemberian jangka panjang bermasalah resistensi dan efek samping selain masalah cost effective dari obat yang dipakai, dan pengobatan terhadap fokus infeksi di hidung dan tenggorokan. Hasil uji kepekaan kuman yang dapat diisolasi dari sekret telinga pasien OMSK menurut sensitivitasnya: Ciprofloxacin 48,50\%, Fosfomycin 30,30\%, Moxifloxacin 30,30\%, Dibekacin 28,79\% dan Gentamycin 25,76\%. Obat tetes antibiotik dapat dipakai sebagai lini pertama dan obat tunggal. Keuntungannya adalah memberi dosis adekuat, 
tetapi penggunaannya harus ototoksik bila masuk ke telinga dalam, karena itu tidak dianjurkan pemakaian lebih dari dua minggu.

Obat tetes telinga jenis ofloxacin terbukti aman, tidak toksik terhadap labirin, efektif sebagai obat tunggal, sehingga direkomendasikan sebagai obat lini pertama untuk dewasa dan anak-anak, namun obat tetes telinga tidak dipakai sebagai profilaksis. Bila terdapat tuli konduktif dan bila perforasi menetap maka idealnya dilakukan timpanoplasti dengan atau tanpa mastoidektomi. ${ }^{3}$

Prinsip terapinya adalah pembedahan, yaitu mastoidektomi, dengan atau tanpa timpanoplasti. Terapi konservatif dengan medikamentosa hanyalah bersifat sementara dan diberikan sebelum dilakukan pembedahan. ${ }^{2}$

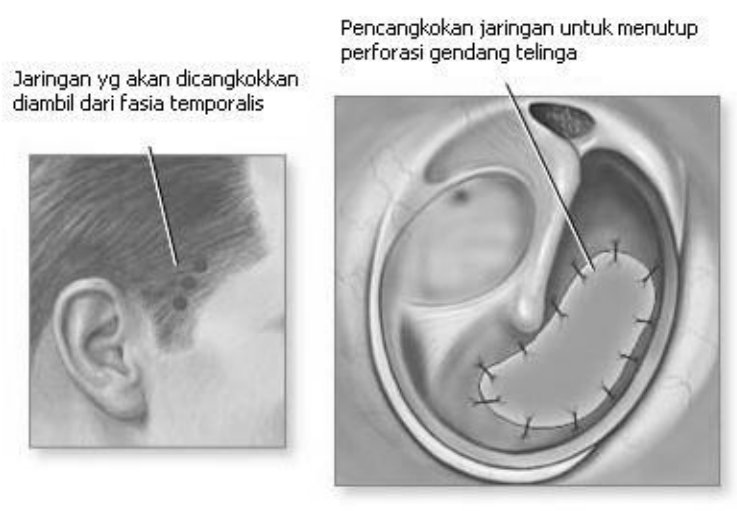

Gambar 1. Timpanoplasti ${ }^{5}$

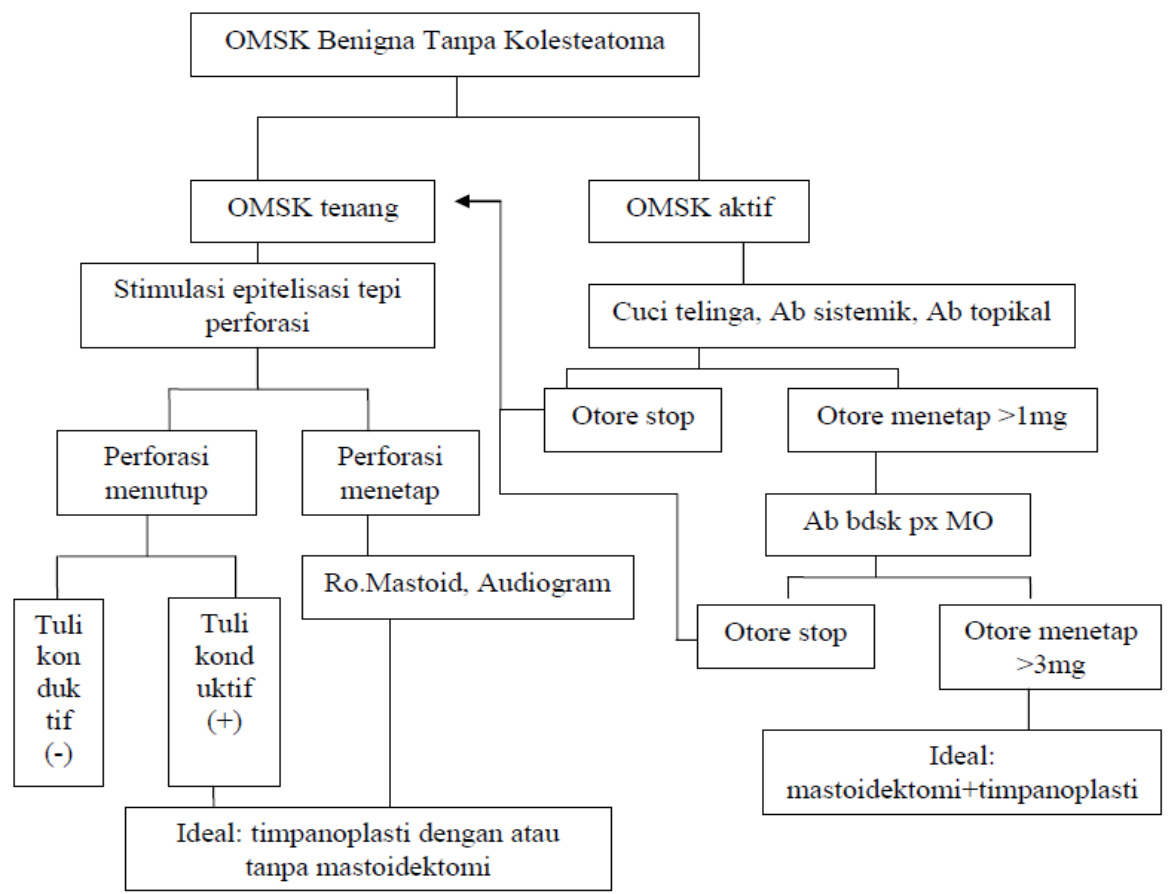

Pada OMSK tipe Maligna pengobatan yang harus dilakukan adalah dengan operasi untuk eradikasi kolesteatoma. Teknik operasi yang dipilih tergantung luas kerusakan dan pilihan ahli bedah. Tindakan atikotomi anterior dipilih apabila kolesteatoma masih sangat terbatas di atik. Bila kolesteatoma tidak dapat dibersihkan secara total dengan tindakan tersebut, dapat dipilih berbagai variasi tehnik eradikasi kolesteatoma, biasanya diikuti dengan rekonstruksi fungsi pendengaran pada saat yang sama, misalnya timpanoplasti dinding runtuh (canal wall down tympanoplasty) atau mastoidektomi dinding utuh (canal wall up tympanoplasty) atau atikoplasti atau timpanoplasti buka-tutup (open and close method tympanoplasty) dan sebagainya. ${ }^{9}$

Pasien OMSK dengan kompliksi intratemporal harus segera dirawat inap dan diberikan antibiotika dosis tinggi secara intravena. Perlu diperiksa sekret telinga untuk pemeriksaan mikrobiologi. Pasien selanjutnya dipersiapkan untuk operasi mastoidektomi sebagai drainase materi purulen disertai dekompresi nervus fasialis 
Gambar 2. Alogaritma Penatalaksanaan OMSK tipe Maligna³

atau petrosektomi, sesuai komplikasi yang ada. ${ }^{10}$ Pasien OMSK yang mempunyai komplikasi dengan tanda-tanda meluas ke intracranial harus segera dirawat dan dirujuk ke dokter spesialis saraf atau saraf anak dan bedah saraf. Antibiotik dosis tinggi yang dapat menembuh sawar darah otak diberikan secara intravena selama 7-15 hari dan periksa mikrobiologi sekret telinga. Tergantung dari kondisi pasien, dapat dilakukan drainase materi purulen secara mastoidektomi dalam anestesi lokal ataupun umum yang dapat pula disertai tindakan operasi bedah saraf. ${ }^{9}$

\section{KASUS}

Pasien laki-laki, 47 tahun, datang dengan keluhan keluar cairan dari telinga kiri sejak 1 bulan yang lalu. Cairan yang keluar berwarna putih kekuningan, sedikit kental, tidak berbau, keluar sedikit-sedikit, dan tidak disertai rasa gatal. Pasien mempunyai riwayat diabetes. Pasien mengaku sebelumnya air sempat masuk ke telinga saat berenang di laut. Pada status present dan status generalis dalam batas normal.

\section{Status lokalis THT :}

Hidung : dalam batas normal

Tenggorok : dalam batas normal

\begin{tabular}{|c|c|c|}
\hline Telinga & Kanan & Kiri \\
\hline Aurikula & $\mathrm{N}$ & $\mathrm{N}$ \\
\hline KAE & Lapang & Sekret $(+)$ \\
\hline Sekret & $(-)$ & mukopurulen \\
\hline Timpani & Intak & Perforasi \\
\hline Tumor & $(-)$ & $(-)$ \\
\hline Tes Penala & \multicolumn{2}{|c|}{ Tidak dilakukan } \\
\hline Hidung & Kanan & Kiri \\
\hline $\begin{array}{c}\text { Nares } \\
\text { Anterior }\end{array}$ & Normal & Normal \\
\hline $\begin{array}{c}\text { Kavum } \\
\text { Nasi }\end{array}$ & Lapang & Lapang \\
\hline $\begin{array}{c}\text { Septum } \\
\text { Nasi }\end{array}$ & Deviasi (-) & Deviasi (-) \\
\hline Mukosa & $\begin{array}{l}\text { Merah } \\
\text { muda }\end{array}$ & $\begin{array}{l}\text { Merah } \\
\text { muda }\end{array}$ \\
\hline Sekret & $(-)$ & $(-)$ \\
\hline Tumor & $(-)$ & $(-)$ \\
\hline
\end{tabular}

\begin{tabular}{|c|c|c|}
\hline $\begin{array}{l}\text { Sinus } \\
\text { Konka } \\
\text { Koana }\end{array}$ & $\begin{array}{c}\text { Normal } \\
\text { Dekongesti } \\
\text { Normal }\end{array}$ & $\begin{array}{c}\text { Normal } \\
\text { Dekongesti } \\
\text { Normal }\end{array}$ \\
\hline Tenggorok & Kanan & Kiri \\
\hline Dispnea & & $-)$ \\
\hline Stridor & & $-)$ \\
\hline Sianosis & & $-)$ \\
\hline $\begin{array}{l}\text { Dinding } \\
\text { belakang }\end{array}$ & \multicolumn{2}{|c|}{ Post nasal drip (-) } \\
\hline Tonsil & $\begin{array}{c}\text { T1, kesan } \\
\text { tenang }\end{array}$ & $\begin{array}{c}\text { T1, kesan } \\
\text { tenang }\end{array}$ \\
\hline Faring & \multicolumn{2}{|c|}{ Mukosa merah muda } \\
\hline Laring & \multicolumn{2}{|c|}{ Tidak dievaluasi } \\
\hline Suara & \multicolumn{2}{|c|}{ Normal } \\
\hline
\end{tabular}

Pemeriksaan penunjang Darah Lengkap dan Foto Schuller tidak dikerjakan. Berdasarkankan gejala pasien, pasien ini didiagnosis banding dengan Otitis Media Supuratif Kronis Tipe Benigna Fase Tenang Sinistra, Otitis Media Supuratif Kronis Tipe Maligna Fase Tenang Sinistra dan Otitis Media Akut Stadium Perforasi Sinistra. Dan berdasarkan anamnesis dan pemeriksaan fisik didapatkan diagnosis kerja yaitu Otitis Media Supuratif Kronis Tipe Benigna Fase Tenang Sinistra. Penatalaksanaan pada kasus ini yaitu diberikan medika mentosa berupa Ciprofloxacine $2 \times 500$ mg, Lapifed 3 x 60 mg dan Ambroxol $3 \times 30$ mg. KIE yang diberikan pada pasien ini yaitu (1) Menjaga kebersihan telinga dengan menjaga telinga tetap kering. (2) Mencegah tertular ISPA karena dapat menjadi predisposisi terjadinya OMSK yang berulang. (3) Makan makanan bergizi, olahraga, dan cukup istirahat untuk menjaga kondisi optimal tubuh sehingga tidak mudah terjadi infeksi. (5) Menjaga kebersihan lingkungan sekitar, lingkungan rumah dan kerja. (6) Kontrol rutin ke poliklinik THT dan minum obat sesuai anjuran dokter. Pengobatan OMSK yang tidak tuntas, virulensi kuman yang kuat, dan keadaan imunitas tubuh yang kurang baik merupakan faktor predisposisi utama terjadinya OMSK yang berulang. Prognosis pasien ini dubius ad bonam selama infeksi terkontrol.

\section{DISKUS}


Pada anamnesis didapatkan bahwa pasien datang dengan keluhan keluar cairan dari telinga kiri sejak 1 bulan yang lalu. Cairan berwarna kekuningan, sedikit kental, keluar sedikit-sedikit, tidak berbau busuk, tidak disertai gatal. Pasien mengatakan telinga kirinya terasa penuh dan krebek-krebek. Pasien biasanya membersihkan cairan yang keluar menggunakan cotton bud. Pasien mengaku sebelumnya air sempat masuk ke telinga saat berenang di laut.

Pasien kadang mengalami sakit tenggorokan dan pilek yang hilang timbul. Faktor predisposisi OMSK yang ditemukan adalah adanya ISPA yang berulang. Infeksi ini menyebabkan tuba Eustachius tersumbat akibat edema. Karena fungsi tuba Eustachius terganggu, pencegahan invasi kuman ke dalam telinga tengah terganggu sehingga kuman masuk ke dalam telinga tengah dan terjadi peradangan. Penurunan daya tahan tubuh juga merupakan salah satu faktor predisposisinya. $^{3}$

Pada telinga kiri pasien terdapat sekret mukopurulen. Sekret pada OMSK bervariasi, bisa encer atau kental, bening atau berupa nanah. Pada membran timpani kiri terdapat perforasi pada bagian sentral regio posterosuperior. Ini memperlihatkan kasus ini merupakan OMSK tipe benigna, yang berarti proses patologi belum mengenai tulang. Pada pasien ini dikatakan OMSK fase tenang karena tidak keluar sekret dari kavum timpani secara aktif. ${ }^{2,3}$

Diagnosis pada pasien ini adalah Otitis Media Supuratif Kronis Tipe Benigna Fase Tenang AS. Infeksi terjadi pada telinga tengah, yang ditandai dengan perforasi mebran timpani disertai pengeluaran secret. ${ }^{2,3}$

Penatalaksanaan kasus pada kasus ini adalah toilet telinga, medikamentosa, dan edukasi. Toilet telinga bertujuan menjaga liang telinga agar tetap kering, sehingga tidak menjadi media pertumbuhan kuman yang dapat memperparah infeksi. Penatalaksanaan secara farmakologis diberikan secara oral yaitu antibiotik, pseudoefedrin/triprolidine $\mathrm{HCl}$, dan ambroxol. Pemberian ambroxol yang merupakan mucolytic agent bertujuan untuk mengencerkan sekret sehingga sekret pada telinga lebih mudah keluar. Pseudoefedrin/triprolidine $\mathrm{HCl}$ bertujuan untuk mencegah terjadinya oklusi tuba, dimana oklusi tuba ini merupakan salah satu faktor predisposisi terjadinya kekambuhan. ${ }^{2,3}$

KIE meliputi menjaga tubuh tetap sehat, memperhatikan kebersihan diri dan lingkungan, patuh terhadap pengobatan, dan kontrol secara rutin ke dokter. Pasien disarankan untuk menjaga agar liang telinga tidak kemasukan air saat mandi, yang bisa dilakukan dengan menggunakan kapas. Pasien juga diingatkan untuk tidak mengabaikan batuk dan pileknya, mengingat infeksi saluran pernapasan atas berulang dan tidak ditangani menjadi faktor predisposisi dari OMSK. Prognosis dikatakan baik selama infeksi terkontrol.

\section{SIMPULAN}

Pasien laki-laki, 47 tahun, datang dengan keluhan keluar cairan dari telinga kiri sejak 1 bulan yang lalu. Cairan yang keluar berwarna putih kekuningan, sedikit kental, tidak berbau, keluar sedikit-sedikit, dan tidak disertai rasa gatal. Pasien mempunyai riwayat diabetes. Pasien mengaku sebelumnya air sempat masuk ke telinga saat berenang di laut. Pada status present dan status generalis dalam batas normal. Pada telinga kiri ditemukan sekret mukopurulen. Pada membran timpani kiri tampak perforasi pada bagian sentral regio postero superior.

\section{SARAN}

Adapun saran yang dapat diberikan oleh penulis atas kasus yang telah diutarakan yaitu: (1) Mengingat banyaknya kasus OMSK beserta kasus OMSK yang telah terdapat komplikasi, dipandang perlu untuk memperhatikan diagnosis awal yang baik dari kasus-kasus otitis media agar tidak masuk ke dalam kondisi kronis. (2) Diperlukan adanya penyuluhan tentang kesehatan dan kebersihan telinga kepada masyarakat pada umunya mengingat kasus OMSK biasa terjadi dikarenakan kebiasaan pasien yang kurang memperhatikan kebersihan dan kesehatan telinganya. (3) Untuk pasien dan keluarga, penulis menyarankan untuk selalu memperhatikan kesehatan dan kebersihan diri secara umum dan kebersihan telinga pada khususnya agar kasus OMSK tersebut tidak kambuh dan tidak menimpa anggota keluarga yang lain.

\section{DAFTAR PUSTAKA}


1. Dugdale AE. 2004. Management of Chronic Suppurative Otitis Media. [Diakses tanggal 11 Agustus 2015] Diunduh dari: http://www.mja.com.au/public/issues/180_0 2_190104/letters_190104_fm-1.html.

2. Djaafar ZA, Helmi, Restuti R D. Kelainan Telinga Tengah. Dalam : Soepardi EA, Iskandar HN editors. Buku Ajar Ilmu Kesehatan Telinga Hidung Tenggorokan Kepala Leher. Edisi ketujuh. Jakarta: Balai Penerbit FKUI; 2012, hal 64-77.

3. Helmi. Otitis Media Supuratif Kronis. Jakarta: Balai Penerbit FKUI; 2005.

4. Parry D. 2005. Middle Ear, Chronic Suppurative Otitis, Medical Treatment. Diakses tanggal 11 Agustus 2015] Diunduh dari:

http://www.emedicine.com/ent/topic219.ht $\mathrm{m}$.

5. Kenna A M et al. Otitis Media with Effusion. In: Head and Neck Surgery Otolaryngology. Vol. 1. London: Lippincott William\& Wilkins. 2001. page: 1071-1079

6. Mansjoer A et al. Kapita Selekta Kedokteran. 3rd ed. Jakarta: Media Aesculapius FKUI; 1999.

7. Jain A. 2003. Middle Ear, Chronic Suppurative Otitis, Surgical Threatment. [Diakses tanggal 16 Juni 2015] Diunduh dari: http://www.emedicine.com/ent/topic215.ht $\mathrm{m}$.

8. Anonim. 2005. Otitis Media Kronis. [Diakses tanggal 11 Agustus 2015] Diunduh dari: http://www.medicastore.com

9. Suardana W. Patogenesis dan diagnostik Otitis Media Supuratif Kronik. Dalam Simposium Penatalaksanaan Otitis Media Supuratifa Kronik, Sinusitis dan Demo Operasi Timpanoplasti. Denpasar: Lab/SMF THT FK Unus/RS Sanglah; 2003. 